\title{
Effect of Chronic Consumption of IBIE Leave (mucuna flagellipes) on Locomotor behaviour in CD-1 Mice
}

\author{
Amah $\mathrm{AK}^{1 *}$, Cornel I², Aduema $\mathrm{W}^{2}$ and Amah $\mathrm{UK}^{3}$ \\ ${ }^{1}$ Department of Medical Physiology, Imo State University, Nigeria \\ ${ }^{2}$ Department of Human Physiology, Gregory University, Nigeria \\ ${ }^{3}$ Department of Chemical Pathology, Nmandi Azlkiwe University Akwa, Nigeria
}

Submission: February 19, 2018; Published: March 13, 2018

*Corresponding author: Amah AK, Department of Medical Physiology, Imo State University, Uturu, Imo State, Nigeria, Email: wadioniaduema@gmail.com

\begin{abstract}
The aim of the study is to investigate the effect of chronic consumption of Ibie leave (Mucuna flagellipes) on locomotor behaviour and thus discover the potential of this underutilized plant in managing locomotor disorders. The open field was used to study locomotor behaviours in 25 Swiss white mice weighing 18g-22g.The mice were grouped into two groups consisting of 9 mice each. Group 1 which served as the control group received normal rat chow $(20 \mathrm{~g})$ and clean drinking water; while Group 2, which serve as the test group received $(20 \mathrm{gw} / \mathrm{w})$ Ibie leave diet. Each mouse was tested in the open field arena for 5 minutes and behaviours scored. ANOVA and post-hoc t-test were employed for statistical analysis and $\mathrm{P}<0.05$, were accepted as significant. The results showed that the frequency of line crosses and rearing were statistically lower $(\mathrm{P}<0.01)$ in the Mucuna flagellipes diet group compared to the control. Therefore, chronic consumption of Ibie (Mucuna flagellipes) diet reduces locomotor behaviour in mice.
\end{abstract}

Keywords: Mucuna flagellipes; Open field maze; Locomotor; Mice

\section{Introduction}

Mucuna flagellipes commonly known as 'Ibie or agbara' in the Igbo part of eastern Nigeria, belongs to the family Fabaceae. It is found in the woodlands of tropical areas of the country [1]. The flowers are creamy white or yellowish while the leaves are greenish with leaflets which are broadly oval [1]. The Mucuna plant posses useful photochemical of high medicinal values to humans [2]. The seed are of good source of food for some ethnic groups in Asia and Africa [3-7]. It is a common practice by the eastern people of Nigeria to squeeze the leaves of Ibie (Mucuna flagellipes) in water and take it orally in order to boast the blood level and to cure other ailments. Therefore, this study is designed to investigate the effects of chronic consumption of the Ibie leave on locomotor behaviour. The date obtained could show the potentials of this underutilized plant in medicinal purpose such as in the management and treatment of locomotor disorders.

\section{Methods}

\section{Animals}

Twenty-five (25) Swiss mice were bought from the Michael Okpara University of Agriculture; Umudike, Abia State, Nigeria, weighing between $18 \mathrm{~g}$ and $22 \mathrm{~g}$ were used for the study. The animals had access to food and clean drinking water ad libitum and were kept in well ventilated room under room temperature $(25 \pm 1$ oC), humidity $(85 \pm 4 \%)$ and $12 / 12$ hours light/dark cycle and allowed two weeks for acclimatization to the research environment before the experiments. The mice were housed singly in metabolic cages where food and water intake were monitored. They were randomly assigned into two groups. Group A and B of 9 mice each. Group A was the control; while groups $B$ were the test group. Animals in group a received normal rat chow, group B animals received the Ibie diet for a period of 30 days [8-11].

\section{Experimental Procedure}

The open field test was used to access locomotor behaviour. The floor of a square plastic board (72X72) with plastic side of $30 \mathrm{~cm}$ high was divided into 16 squares. A central square (18 $\mathrm{x} 18 \mathrm{~cm}$ ) is drawn in the middle of the open field. The central square has sufficient space surrounding it to give meaning to the central location as being distinct from the outer locations. The mice were individually placed in the corner of the open field maze and allowed to explore the area freely. The activity level was expressed as the total number of squares crossed and the rearing frequency during a 5-minute testing period. The maze was cleaned with $70 \%$ ethyl alcohol and permitted to dry between trials. Mice were placed back into the colony room while cleaning the apparatus in bright light conditions (Figures $1 \& 2)$. 


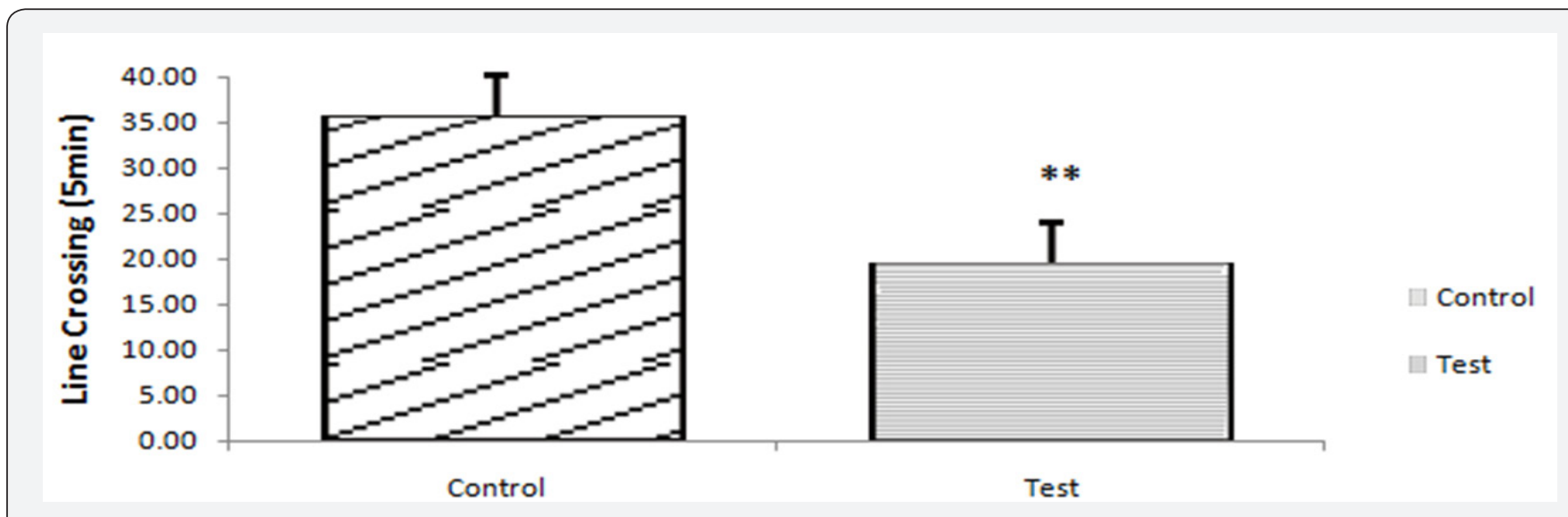

Figure 1: Comparison of Line Crossing in the open field maze, in the control and Ibie Leave treated groups. Values are mean \pm SEM, $n=$ $9,{ }^{* *} p<0.01$ vs control. 8

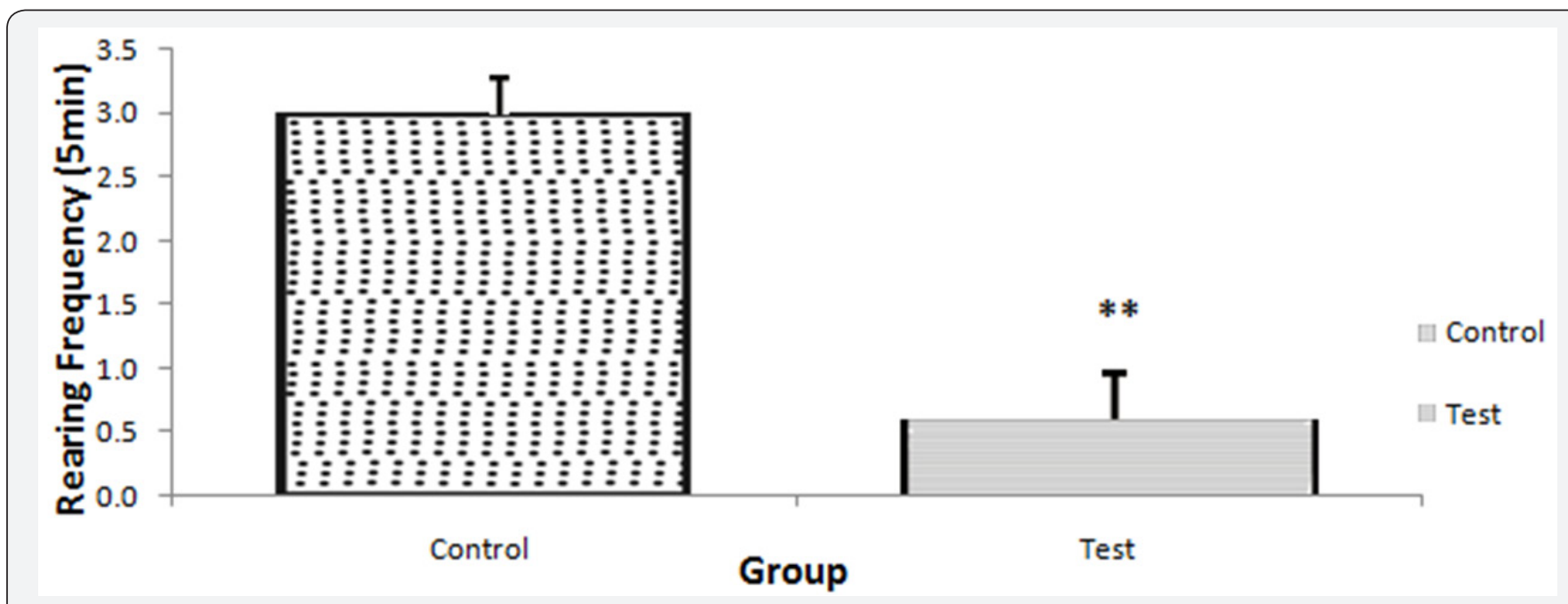

Figure 2: Comparison of Rearing Frequency in the open field maze, in the control and Ibie Leave treated groups. Values are mean \pm SEM, $\mathrm{n}=9,{ }^{*} \mathrm{p}<0.01$ vs control.

\section{Statistical Analysis}

All results were shown as mean \pm SEM. Differences between means of the two groups were compared using Student's t test or the Mann-Whitney u test, depending on whether the data were normally distributed. SPSS for Windows 11.5 software was used for statistical analysis. In all cases, significance level was set at $\mathrm{P}<0.05$.

\section{Results}

\section{Behaviors scored in the open field maze (OPM)}

a. Line Crossing: Figure 1 compares the frequency of line crosses between the two groups of mice for locomotor behavior. The number of lines crossed by the mice were, $35.80 \pm 4.97$ (control) and $19.60 \pm 1.32 / 5 \mathrm{mins}$ (ibie leave).The results shows that the frequency of line crosses of the Ibie leave fed mice was statistically lower $(\mathrm{P}<0.01)$ compared to control (Figure 3).

b. Rearing Frequency: The frequency of rearing in the open field for control mice and Ibie leave was $3.00 \pm 0.70$ and $0.60 \pm 0.04 / 5 \mathrm{mins}$ (Ibie leave) respectively. The graph in Figure 2 shows that the frequency of rearing in the test group when compared was significantly different at $(\mathrm{P}<0.01)$ compared to control [10-11].

c. Centre Square Duration: Figure 3 compares centre square duration which is a measure of locomotion in the two experimental groups. The values are: $0.60 \pm 0.00$ (control) and $0.00 \pm 0.00$ (Ibie leave). The duration of centre square was not significantly different compared to control.

d. Frequency of Sap: The frequency of stretch attends posture between the two experimental groups is in Figure 4. The values are: $0.80 \pm 0.37 / 5 \mathrm{mins}$ (control) and $2.20 \pm$ 0.48 (Ibie leave).The frequency of SAP of the group of fed Ibie leave was statistically higher $(\mathrm{p}<0.05)$ compared to control.

e. Freezing Duration: The freezing duration between the mice administered 5-Hydroxytryptophan and control are: $41.80 \pm 6.35 \mathrm{secs}$ and25.00 $\pm 3.91 \mathrm{secs}$. The duration of freezing for the group of mice fed Ibie leave was significantly lowers (0.05) compared to control (Figures $4 \& 5$ ). 


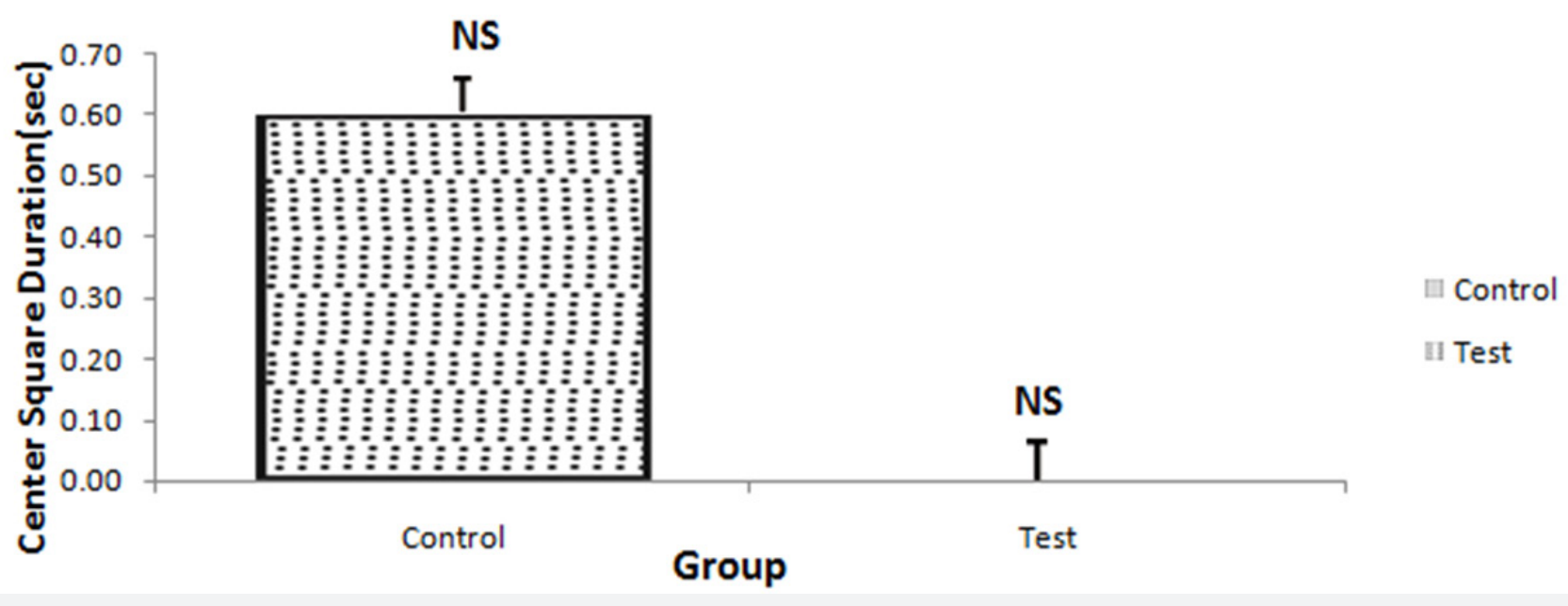

Figure 3: Comparison of Center Square Duration in the open field maze, in the control and Ibie Leave treated groups. Values are mean \pm SEM, $n=9, \mathrm{NS}=$ not significant.

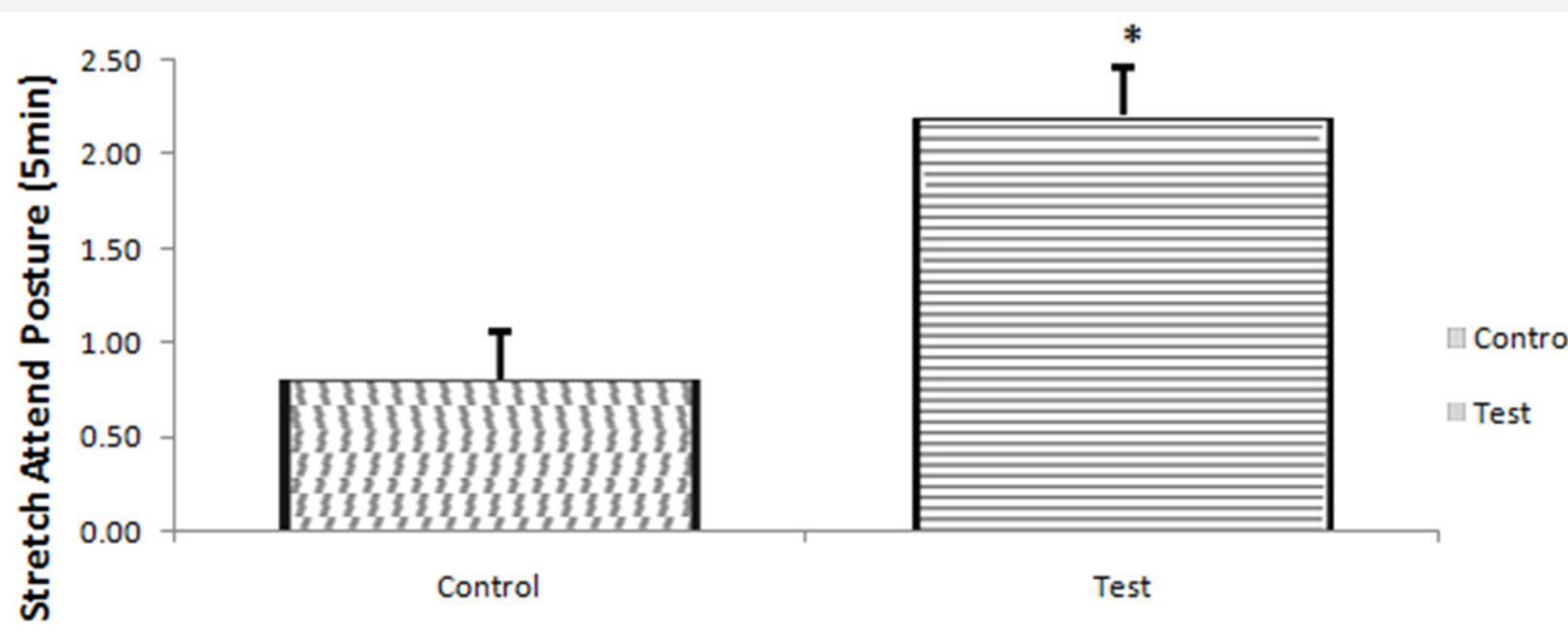

Figure 4: Comparison of Stretch Attend Posture in the open field maze, in the control and Ibie Leave treated groups. Values are mean \pm $\mathrm{SEM}, \mathrm{n}=9,{ }^{*} \mathrm{p}<0.05$ vs control.

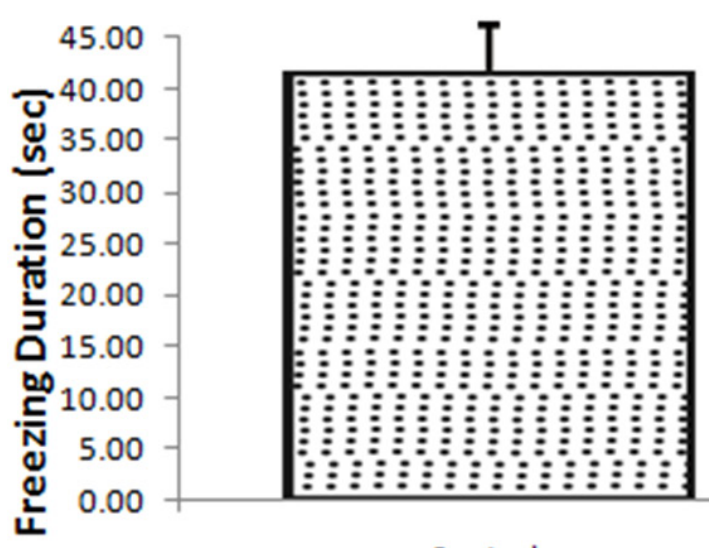

Control

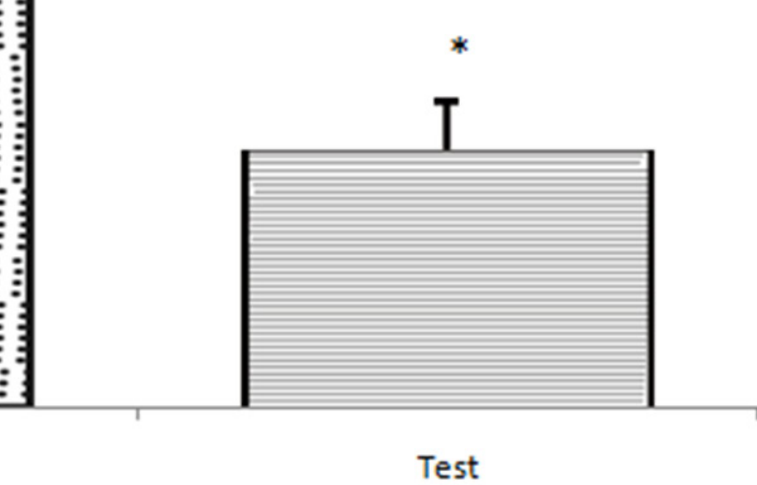

$\square$ Control

마 Test

\section{Group}

Figure 5: Comparison of Freezing Duration in the open field maze, in the control and lbie Leave treated groups. Values are mean \pm SEM, $n=9,{ }^{*} p<0.05$ vs control. 


\section{Discussions}

The open field arena is used as an assay to access locomotor, exploratory and even anxiety related behaviour in animals (Walsh and Cummin, 1976).The frequencies of line crosses and rearing were the direct indices used in measuring locomotors behaviour even though the centre square entries, centre duration, freezing duration and frequency of stretch attend posture are also other behavioural indices used in measuring locomotors behaviour. The results of our research work showed that the frequencies of line crosses and rearing were significantly lower in the mice treated with the Ibie leaves when compared to the control. Thus, indicating a decrease in the locomotors behaviour in the mice fed the Mucuna flgellipes. Similarly the stretch attend posture was also significantly higher for the test group compared to control.

The duration of centre square entry did not differ compared to control while the duration of freezing was lower for the test group compared to control. Locomotion is been control by the central pattern generator of the spinal cord. Increase in dopamine level directly or indirectly result in hyper locomotion. Therefore, increase dopamine level may probably be the reason for the hyperthermia of the brain and this has been known to be in correlation with increase locomotion $(26,27,28$, and 29).Our study revealed that the Ibie leave may have an inhibitory effect on the motor cortex such as the cerebellum thus decreasing locomotor activity in the experimental animals.

\section{Conclusion}

The results of this study indicate that the Mucuna flagellipes leaves decrease locomotor/exploratory behaviour in mice.

\section{Acknowledgement}

The authors wish to acknowledge the assistance of $\mathrm{Mr}$. Oreabosi Michael in collection of the sample and Mr. Uchenna who help in the laboratory.

\section{References}

1. Hutchisonb J, JM Diaziel (1973) Flora of West Tropical Africa. $2^{\text {nd }}$ edn. The whitefrairs Press Ltd, London 1: 561.

2. Shridhar KR, R Bhat (2007) Agrobotanical, nutritional and bioactive potential of unconventional legume-Mucuna. Livestock Res Rural Dev 19: $126-130$.

3. Iyayi EA and Egharevba (1998) Biochemical evaluations of seeds of an underutilized legume (Mucuna utilis).Nig J Anim Prod 25: 40-45.

4. Adebowale KO, Lawai OS (2005) Variability in the physiochemical and anti-nutritional attributes of six Mucuna species. Food Chemistry 89: 37-48.

5. Afolabi AO, BA Osuntogun SR, Adewusi 00, Fapojuwo FO, Ayorinde FE, et al. (1985) Preliminary nutritional and chemical evaluation of raw seeds from Mucun a solanei: An underutilized food source. J Agric Food Chem 33: 122-124.

6. Diallo OK, S Kante, R Myhrman, M Soumah, NY Cisse (2002) Increasing farmers adaption of Mucuna pruriens as Human Foods and Animal Feeds in the Republic of Guinea. In: Food and Feed from Mucuna: Currentuses and the way forward, flores BM; M Eilitta, R Myhrman, L B Carewand, RJ Caskey (Eds) World Hunger Research Center, Tegucigalpa, Hunduras p. 60-72.

7. Emenalom 00, IC Okoli, ABI Udedibie (2004) Observations of the pathphysiology of weaner pigs fed raw and preheated Nigerian Mucuna pruriens(velvet beans) seeds. Pak J Nutr 3: 112-117.

8. Brown PL, Kiyathin EA, Wise RA (2003) Brain hyperthermia is induced by methamphetamine and exacerbated by social interaction. J Neurosci 23: 3924-3929.

9. Brown PL, Kiyathin EA (2004) Brain hyperthermia induced by MDMA (ecstacy): modulation by environmental conditions. Eur J Neurosci 20: 51-58.

10. Mesembe O, Bisong S, Ekong M, Ekeoma A (2008) Neurobehavioral activity in Albino wistar Rats in the open field maze following long term Tobacco Diet ingestion. The Internet Journal of Neurology 10(2): $1-6$.

11. Kiyatkin EA (2005) Brain hyperthermia as physiological and pathological phenomena. Brain Res Rev 50: 27-56.

Your next submission with Juniper Publishers will reach you the below assets

- Quality Editorial service

- Swift Peer Review

- Reprints availability

- E-prints Service

- Manuscript Podcast for convenient understanding

- Global attainment for your research

- Manuscript accessibility in different formats

( Pdf, E-pub, Full Text, Audio)

- Unceasing customer service

Track the below URL for one-step submission https://juniperpublishers.com/online-submission.php 